\title{
Cancer-related Cognitive Dysfunction
}

National Cancer Institute

\section{Source}

National Cancer Institute. Cancer-related Cognitive Dysfunction. NCI Thesaurus. Code C162756.

The effects of cancer and its treatments on cog nitive processes. 